\title{
The European Two-Level Game in Central Asia: Visegrad Countries and Kazakhstan
}

\author{
Peter PlentA*
}

\begin{abstract}
Since 2007, the European Union has developed a strategy towards Central Asia. Relations with the region have created an opportunity to focus on a wider spectrum of interests across different levels of EU foreign policy. This article examines the "two-level game" between EU member states (from Central Europe) and EU institutions in Brussels regarding economic interests versus values agenda with the focus on Kazakhstan. In this game, the EU's member states focus on developing trade and economic relations while they let space for the EU's institutions to discuss sensitive issues, such as democracy promotion and human rights dialogue. This is the case for the Visegrad countries (the Czech Republic, Hungary, Poland and Slovakia) that prefer a pragmatic approach towards Kazakhstan as the most important country in the Central Asian region.

Keywords: European Union, Visegrad States, Kazakhstan, Central Asia, Interests, Values
\end{abstract}

* Assistant Professor, International University of Sarajevo, Sarajevo, Bosnia and Herzegovina; E-mail: pplenta@ius.edu.ba

DOI: $10.16934 /$ isr.17.2.201612.79 


\section{INTRODUCTION}

In the 1990s the European Union did not attach strategic significance to Central Asia and had no strategic vision for the region. In fact, the region was given a low priority level, because it was deemed to be of peripheral concern for the EU (Yazdani 2008, 247). This situation has changed since the September 11, 2001, terrorist attacks and the military operation in Afghanistan. Central Asia played a significant role due to geographical proximity and its willingness to provide military bases for logistical support of the operation. The shift in focus to the region also coincided with the electoral victory of President Vladimir Putin in Russia, the development of Chinese economic diplomacy and the construction of new routes for oil and gas. The European Union has tried to increase its presence in this area over the last few years through its new strategy, development aid, technical assistance and institutional tools such as the creation of the EU's special representative position for Central Asia.

As Sedelmeir (2006, 118-119) correctly stated, one of the most important items for the European Union in the international politics is the promotion of human rights and democracy. Even more importantly, it is one of the characteristics of the EU's collective identity. Among the core values of human rights and democracy are peace, liberty, democracy, the rule of law, and respect of human rights (Manners 2002, 242). Human rights violations can result in the suspension of co-operation or the imposition of economic sanctions, which is known as negative conditionality. In practice, EU conditionality clauses have a wide geographical scope, but they are not universal (Pérez de las Heras 2015, 82). The basic idea that inspired the article was stated by Manners $(2002,236)$. According to Manners, the European Union as a promoter of norms displaced the state as the center of concern. Member states in several cases, despite acceptance of the core values, put the responsibility for values promotion on the level of European Union. Many analyses focused on potential conflicts and disputes as consequence of this division. For instance, OHCHR $(2011,8)$ report stated that such situation would only serve to undermine the role of the EU in the eyes of its international partners and other third states. However, in the case of Kazakhstan, we can see a relatively effective division of roles.

Kassenova $(2008,128)$ pointed out that there are two key questions for the EU in the region. The first deals with the problem how to balance the goals of the promotion of democracy and human rights with the realistic interests of securing access to the region's energy reserves. The second question addresses the logistics of engaging and not "losing" the region, while also not becoming too soft on local authoritarian regimes. We can call such division as "interests vs. values issue." For the European Union, the region is too distant, and Brussels experiences difficulties in executing its democratic and value-based agenda on the ground (Romanowski $2016,1)$. Although this is core question for the EU, according to Youngs (2016), 
he also adds that the relationship between values and interests is complex, and sometimes there will be a trade-off between the two, while other times certain values can enhance self-interests, further complicating the process of defining what is a "value" as opposed to an "interest."

I argue that European Union member states known as Visegrad countriesthe Czech Republic, Hungary, Poland and Slovakia-employ a "two-level game" in relations with Central Asian countries. The primary point of this game lays in the difference between a "national" approach and a "European" approach to the region. The member states voluntary transfer problematic issues such as democracy promotion and human rights dialogue to the EU institutions because of preferences for their economic and trade interests. On the level of EU institutions, these countries support the values agenda of the European Union. However, on the level of bilateral relations, the countries focus mainly on economic topics and mutual trade. Such division of roles allows them to promote economic cooperation without opening sensitive issues.

Institutional competition in the form of turf wars between the supranational and intergovernmental levels of the EU's institutional architecture can result in a potpourri of contradictory-and thereby ineffective-policies (Boas 2012, 1). At first glance, it seems that the issue was resolved by the differentiation of roles between member states and the European Union institutions. The states focus on their economic interests, and the EU has concentrated more on technical assistance, human rights dialogue and the promotion of European democratic values. In the case of Central Asia, promoting European values has become the responsibility of the EU institutions, while member states are involved on a voluntary basis. However, such a division of roles has never been made on the basis of the official decision but rather on the basis of states' rational behavior. As it was highlighted by representative of one Visegrad country in Kazakhstan - "there is such trend within member states to pass all these common problems to the European Union, the EU is the 'boy' for this. We are ready to help them, but we don't want to be speaking aloud" (AST-2013-11-26). On the other hand, such an approach has brought occasional displeasure to the EU level. A representative of the European External Action Service reflected this attitude: "Member states leave human rights and democracy to the European Union. It is a little bit frustrating for us on the EU side because it would be a far more powerful message if the member states pursue this bilaterally as well. Some of them do, but they mostly leave it to us" (BRU-2013-10-23). Although "European" foreign policy and the foreign policies of EU members' states are closely linked, sometimes member states would prefer a division of roles if it is in their national interests. At least some of the member state took this "advantage" without any risk because there are European Union's institutions taking the role of promoter of human rights and democracy.

Visegrad countries provide the interesting group for analyses of the two-level 
game in Central Asia. Poland, the Czech Republic, Slovakia, and Hungary launched cooperation, which, with its pros and cons, has its 25th anniversary. Visegrad countries have created a relatively homogenous group of states in central Europe during previous 25 years, with similar history and problems. The V4, today with a certain trademark, through a transition to democracy and free market economy, has defined a fundamental objective the moment the venture was founded-the accession to the European Union and NATO (Romanowski 2014).

All four countries have embassies in Kazakhstan, relatively rich contacts and developed economic, trade, diplomatic, historical and cultural ties. Kazakhstan was chosen as the most developed and important country in Central Asia for the European Union and the Visegrad group. There has been significant development of its economy and natural resources production in last 15 years. Another factor is the multivectoral and active foreign policy, which has successfully created ties with European countries as well as European Union institutions. This factor was further stressed by ambassadors of EU countries. "I think that objectively, for economic reasons, but also for foreign policy reasons, Kazakhstan is a separate identity from the other four Central Asian countries. It plays a much larger role in the world and regional politics than do other states in the region" (AST-2013-1127). The first part of the article concerns itself with the "level one"-EU's relations with Central Asia and Kazakhstan in particular, while the second part of the piece focus on "level two"-relations between the Central European Visegrad group countries and Kazakhstan. Such division is necessary for understanding connection and division between two levels. Moreover, individual policies towards Kazakhstan are framed by the wider context of relations between the European Union and Central Asia.

This article seeks to evaluate the actual relations between V4 countries and Kazakhstan within the framework of relations between the EU and Central Asian countries. The primary goal is to analyze how "interest vs. values issue" has been resolved in the relations with Kazakhstan, the country that is criticized, by NGOs and some of the international institutions, for its level of democracy and human rights protection. I do not attempt to provide a comprehensive analysis of the EU's human rights policy in the Central Asia, instead I am focusing on preferences of the EU institutions and central European states in relations with Kazakhstan. The main method used in this article is data analysis. The data includes official documents as well as secondary sources. Additional information was gathered through interviews in Brussels and Kazakhstan at the end of 2013.

\section{EUROPEAN UNION RELATIONS WITH KAZAKHSTAN}

The European Union approved the EU and Central Asia: Strategy for a New Partnership in July 2007, with the goal of intensifying cooperation with the region. 
It defined priorities such as political, energy and human rights dialogues; created the position of the European Union Special Representative for Central Asia; and identified goals where should be financial allocations. It was part of the "Neue Ostpolitik" initiated by the German Presidency of the EU in order to intensify cooperation with post-Soviet countries (Stepniewski 2012, 130). The Strategy was the important step for the European Union in Central Asia, and it has become a starting point for later initiatives. Nevertheless, as Boonstra $(2011,6)$ underlines, EU's policy towards Central Asia has been overshadowed by other priorities, such as establishing the European External Action Service (EEAS), the economic crisis, the war between Georgia and Russia and the situation in Afghanistan. The attention of the EU institutions focused on other parts of the world with a higher priority for Europe. That was one of the reasons why some of the experts called for a revision of this Strategy. Other causes were the Strategy's overly general priorities and modest results (with the exception establishing regular political dialogue).

EU institutions, representatives of members' states, analysts and researchers often differ dramatically on their assessments of various EU Central Asia strategies and policies. The key difference is on the expectations of what can be changed and how to do so. In the words of one Kazakh analyst (ALM-2013-12-12), "any policy which is going against the vital interests of regimes and presidents has no chance to be successful." No doubt, that opening normative agenda is a sensitive issue for Central Asian governments. Nevertheless, the EU is the only organization that regularly brings this issue "to the table" with Central Asian countries.

The EU Strategy towards Central Asia was revisited in 2012, with a stronger emphasis on security issues. Nevertheless, these changes have been described more often as an evolution than as a revolution. There were no demands for fundamental changes, either from the European institutions or EU member states. As one of the EEAS staff stressed, "we saw in the review that member states are happy how things are going in vis-à-vis Central Asia. We look at the idea of doing something extremely different, but in fact, what we are doing now, seems to be, more or less, focusing on areas of concern and the areas of interests for both sides" (BRU-201310-23). One of the representatives of member states in $\mathrm{COEST}^{1}$ expressed a similar opinion, that the strategy is in principle a good one, and they appreciated the leading role of the office of the EU special representative for Central Asia (BRU-2013-10-24). Three main reasons can explain such attitudes of member states. As mentioned above, it is not easy to propose radically new solutions altering relations with the region. The second reason is that the objections of the Strategy were highly ambitious, in term of proposing serious changes in politics; however Central Asian states are willing to cooperate only in several areas. Finally, EU institutions play leading roles due to limited interests and capacities of embassies of most member states in Astana. Visegrad member states welcomed that EU institutions took the leading role in promoting a normative agenda in Central Asia, 
allowing them to focus on economics.

Relations between the European Union and Kazakhstan have significantly increased in the previous years, and there was interest from Kazakhstan's side as well, mainly due to its candidacy for OSCE Chairmanship. One of the examples of this proximity was a program titled "The Path to Europe," even though it was a part of Kazakhstan's campaign to receive the Chairmanship. The significance of Kazakhstan, as the most important country in Central Asia as well as the primary partner for the European Union in the region, is growing in the political, economic, trade and security spheres. "Kazakhstan stands apart from its Central Asian neighbors in its eagerness to integrate with European structures. Astana sought observer status in the Council of Europe and explored the possibility of being included in the European Neighbourhood Policy" (Kassenova 2010, 51). Kazakhstan is perceived as a regional success story, and it is responsible for most of Central Asia's trade and investment and would like to be recognized as a pillar of the modern Silk Road (Romanowski 2016, 4).

Despite the debate regarding Kazakhstan's accession to the Eastern Partnership, today it does not seem to be a real possibility. From the European perspective, Kazakhstan is too distant. The country's integrationist ambitions are connected with the Eurasian Economic Union, a Russian-led integration project in a postSoviet sphere. Nevertheless, the European Union is the largest trading partner of Kazakhstan, accounting for $40 \%$ of Kazakhstan's exports. ${ }^{2}$ Together with a stronger and more active foreign policy of the EU, this has resulted in deeper relations between the EU (as well as member states) and Kazakhstan. Still, there are also obstacles for stronger collaboration. "On the one hand, we want a closer relationship. At the same time, we are not ready to carry out major reforms-allow some cooperation here, do not put too much pressure on us, but at the same time develop a better trade regime" (ALM-2013-12-12). Such attitudes among the Kazakh elites help explain the division of roles between the EU and member states. Central European countries are not in a position where they can push liberal and human rights agendas without threatening economic interests. Moreover, they stand apart from some of EU activities (such as meetings with representatives of the opposition and independent organizations and journalists).

If we analyze the results of the strategy in relations with Kazakhstan, we can see the difference between declared ambitions and the real situation. This strategy helps increase contacts at the highest level through regular meetings between European and Kazakh representatives. "Kazakhstan has increased its ties with Europe. However, apart from political dialogue, I don't think that relations have increased so much" (ALM-2013-12-12). It is possible to identify several reasons for this situation. First, cooperation with results is possible to develop only in areas on mutual interests. Therefore, this complicates achieving results in areas such the EU Rule of Law Initiative or Human Rights Dialogue. During my inter- 
views, I met several times with an opinion of Kazakh political scientists, who described the approach of the EU institutions as "mentoring," which does not seem to be the best way to promote change. This was stressed by one Kazakh analyst, who underlined that "there is a lot what we can learn from Europe. There is something to offer, but it should be done in the right way, with a better understanding of context" (ALM-2013-12-12).

Assistance programs are another area that need to be reformed since they remain complicated and over-bureaucratized. Such impediments mitigate effectiveness. As European Court of Auditors (2014) stressed in its report, "implementtation was slow overall, though with some significant variations. The regional programs did not achieve a genuine regional dimension; a significant share consisted merely of 'multi-country' facilities available to each partner country individually." Moreover, there is a similar view in the region and as exemplified by one expert, "it should be less bureaucratized and maybe involve more local expertise" (ALM-2013-12-12). Despite these problems, the EU provided Kazakhstan with more than 60 million Euros from 2007 to 2012. Here, 91\%was channeled to government agencies using a project-oriented approach, and the remaining $9 \%$ went to civil society organizations via grants and calls for proposals (Tsertsvadze and Boonstra 2013, 8).

There is also a difference between declared ambitions and the real situation regarding human rights dialogue and the promotion of democracy. NGOs often criticize the EU because of the lack of progress on human rights and democracy in Kazakhstan. This critique is maybe too severe. As highlighted several times during my interviews, "stability first" is not only the slogan of Kazakh regime but also of the bulk of the population, reflecting the prioritization of economic prosperity and stability over political rights and freedoms. There is a difference in the perception of democratization and human rights agenda as well. While democratization, in the opinion of some of the political scientist in Kazakhstan, is viewed as a threat to stability, human rights are universal and should not be violated (ALM-2013-1212b). The case of Kyrgyzstan was mentioned as a negative example of what "democratization" can bring-unrest and instability.

Lastly, we can also identify different attitudes, between the European Union and its member states, towards the human rights agenda in the region. States have transferred the responsibility for this issue to the EU level. In practical terms, it is useful for them, because they can avoid controversy. For instance, Zhanaozen events $^{3}$ influenced relations between the EU and Kazakhstan due to the resolution of the European Parliaments about these events in 2011. "There was some irritation at the top. Maybe it was not the only thing, but people at the top [of Kazakh elite] were upset with this resolution of the European Parliament" (ALM-2013-1212). As declared by one of the EU's staff, the resolution of the European Parliament had an impact on relations. "We had quite a lot of difficulty in 
planning Ms. Ashton's ${ }^{4}$ trip to the region because it came just two weeks after the big resolution in the European Parliament, which was really critical for Kazakhstan. It took a lot of diplomatic effort to keep it on track" (BRU-2013-10-23).

On the other hand, representatives of member states, as well as representatives of the EU, stressed progress in human rights. "In diplomatic terms, these discussions are frank but constructive for the most part" (BRU-2013-10-23). Furthermore, some of the Kazakh analysts argue that without the EU, the human rights situation could be worse. "I don't think that human rights dialogue is completely useless, at least in order to know that somebody cares or is looking to them. I think that our situation with human rights would have been worse without the EU" (ALM-201312-12).

Beside the Strategy, the Partnership and Cooperation Agreement (PCA) formed the basis of the EU-Kazakhstan relations. The agreement was signed in 1995 and has been in force since 1999. ${ }^{5}$ These accords provide a legal framework for economic cooperation between these countries and the EU and its member states, covering issues such as trade, business and investment, and legislative and financial cooperation (Tsertsvadze and Axyonova, 2013, 2). The majority of activities in the PCAs focused on trade and economic relations, with only a small part of them being oriented towards human rights, the rule of law and democratization. As Hoffman $(2010,94)$ underlines, although the PCAs are based on compliance with the principles of democracy, human rights and the rule of law, the wording remains vague when it comes to the concrete promotion of these principles in the Central Asian context. Contrary to the PCA, the Central Asia Strategy has brought a real focus on this agenda.

There were requests from the Kazakh government to launch negotiations on a new agreement. In 2009 Cooperation Council concluded that the existing PCA did not reflect the extent of the cooperation between the parties and agreed on the need to reach a new agreement (Tsertsvadze and Axyonova 2013, 2). New negotiations the second generation of PCA started in 2011 under the leading of European External Action Service. Despite official statements about a "stronger and enhanced" PCA, negotiations were more complicated that it was expected. As one of the EU member state ambassadors noted:

Before we had a very comprehensive text and during this round in Astana [in 2013], Kazakhstan consistently tried to narrow it down, to make it more general. This created a lot of complications, on the EU side, there were big parts of the text that have been agreed on. Now, Kazakhstan came up with a different concept that was a bit confusing. The reason was also very confusing, because they argued that they could not translate everything into the Kazakh language (AST-2013-11-27). 
Another EU member states ambassador remarked that "the EU missed the best time for the conclusion of PCA, the negotiations are too long. Moreover, Kazakhstan is in a stronger position with more foreign policy possibilities now" (AST-2013-12-05). Kazakhstan is focusing more on Eurasian economic union and relations with South East Asian countries. According to the opinion of EU member states' ambassadors and their staffs, another explanation could be different expectations of both sides. "They want a more general agreement, a document without any strict or concrete sentences, which is completely different from the position of the EU, which wants a concise statement that includes all responsibilities and possibilities in cooperation" (AST-2013-11-27). Nevertheless, negotiations in 2014 brought an important breakthrough, and the two parties agreed on the full text of a draft agreement, which is to be initialed during the last round of negotiations (Eurasian Council on Foreign Affairs, 2014).

\section{VISEGRAD COUNTRIES AND KAZAKHSTAN: IT'S THE ECONOMY STUPID!}

The second level of the "game" represents interests of member states, which intentionally focus on the economic dimension of relations with Kazakhstan and avoid sensitive issues. Nevertheless, Visegrad countries, in relations with Central Asian countries, have experience with situations where economic interests conflict with human rights agenda. When Czech President Miloš Zeman personally initiated visits of the Uzbek and Turkmen leaders, it caused a wave of criticism not only from human rights organizations but also from a majority of Czech political representatives. The visit of Uzbek President Karimov was cancelled due to a lack of interest by members of the Czech government. Another illustration was the crackdown of the Slovak police against a Kazakh protester (with a Polish passport) during the official visit of president Nazarbayev in Bratislava in 2007. The officials justified this action on the grounds of the protester screaming during the Kazakh anthem and welcoming ceremony of the Kazakh president. She spent several hours in a police station. Emergency services were called because of injuries causing by the police. This situation was heavily criticized by non-governmental organizations, and the Minister of Interior finally apologized for this incident. In an embarrassing effort to compensate the protestor for her injuries, government officials offered her a free stay at a local spa. A more direct illustration of the influence of relations between V4 countries and Central Asia is the presence of the Kazakh opposition group Open Dialogue Foundation in Poland. According to the Polish representative this could be the reason why relations between Poland and Kazakhstan are not as good as they could be.

Despite these issues, the most important part of relations between V4 countries and Kazakhstan lays in trade and economic cooperation. The Czech Republic and 
Poland are well known for the promotion of human rights and democratization in the cases of Belarus, Ukraine or Cuba. ${ }^{6}$ However, this is not the case for Kazakhstan or Central Asia in general. Slovakia and Hungary are considered more "pragmatic" approach in their foreign policy and avoid raising sensitive issues.

All four countries, the Czech Republic, Hungary, Poland and Slovakia, have embassies in Astana and some of them also have consulates in Almaty. The diplomatic relations between the V4 countries and Kazakhstan were established in first half of the 1990s, followed by opening embassies in capitals. The only exception is Slovakia whose embassy in Kazakhstan was not opened until August 2004. Kazakhstan has become the most important partner from the region and embassies in Astana usually cover some or all of Central Asia. There are several examples of mutual activities among Visegrad countries embassies, such as the hosting of film festivals and scientific conferences. On the other hand, these states view one another as competitors in the economic field.

Trade and economic cooperation have become a priority for Visegrad countries, especially in recent years; cooperation with Kazakhstan has increased as a result of business considerations and governmental agreements. However, there are still difficulties present in economic relations. One of the complaints mentioned during my interviews was related to cooperation with smaller companies. There are differences in cooperation with large enterprises, which are described as "western" and small and medium companies which are still in the "Soviet thinking model" (AST-2013-12-05). These companies were marked as not fully reliable. Another problem is unclear and unstable legislation, weak enforcement of law and corruption. On paper everything is acceptable, but in reality there are problems with custom services, the legislation changes rapidly, and often the law is not strict (AST-201311-26). The most significant problem in business cooperation, identified during interviews in Astana, is the level of corruption in the country. "Our companies don't want to speak about this very loud, because of corruption on different levels of authorities" (AST-2013-11-26).

Despite the fact the member states have the right to create policy in Brussels, Central Asia is not a "big issue" for Visegrad countries. Therefore, they usually tend to agree with the proposals of European institutions. Thus, EU institutions have taken the leading role in European policy towards Central Asia. "Positions are usually agreed upon in Brussels. An opposite example is represented by situations when the EU member states write a joint report to Brussels, which can happen on an ad hoc basis, as an initiative of an EU delegation or the initiatives of member states if there is an agreement" (AST-2013-11-27). Some of the countries turned this situation to their advantage. Problematic issues are communicated by EU institutions, which have allowed member states to focus on trade and economic relations. The "division of roles" with the European Union brings benefits to the Central European countries. As one of the ambassadors declared about the situation, 
"Cooperation with the EU mainly consists of information exchange and coordination in some of the steps. Human rights issues are not discussed; one of the reasons is lying in the limited capacity of embassies and the active role of the EU in this area" (AST-2013-12-05). The main advantage of the European Union's presence in Central Asia is better coordination, consultations, and mutual activity, as it was stressed during the interviews in Kazakhstan. "Especially in the economic sphere, they are very helpful, and there is a good cooperation thanks to trading officer meetings every month. We can exchange our views thanks to the EU, with an increased level of cooperation between other member states during these meetings" (AST-2013-11-26).

Although human rights and democratization issues are the most complicated topic in mutual relations, it is mostly the responsibility of EU representatives. Even staff members of European embassies admit this fact, and the responsibly for this topic rests at the EU level. "The help of member states or their role in human rights promotion is limited. This subject here in Astana has completely passed onto the EU, and it represents all member states in these areas" (AST-2013-11-26). Contrary to several other EU countries, Visegrad countries avoid engaging in these topics related to human rights and democratization. For instance, when the EU delegation in Kazakhstan organized a meeting with the nongovernment sector, member states were invited as observers, only a few states were there (AST-201311-27). There were none of Visegrad countries. Another ambassador mentioned only limited capacities of embassies with a few staff members, for regular and deep focusing on this issue (AST-2013-12-05). However, the Swedish representative regularly participated, although the Swedish embassy had less staff than Visegrad countries.

There is also doubt if EU activities directly help member states to develop mutual relations. Several member states' representatives are rather sceptical about it. "I don't think that the Strategy could help increase these connections, even between Kazakhstan and the EU. The strategy is a very good idea, but when you talk about concrete ideas or projects, I am not really sure" (AST-2013-11-26). A similar opinion was expressed by one of the European ambassadors. "I don't think that the Central Asia Strategy has a high impact, I don't think so. However, it may be difficult to judge and very difficult to measure" (AST-2013-11-27).

\section{The Czech Republic}

The Czech Republic's relations with Kazakhstan are on a standard level with regular mutual visits on the highest level. In 2012, Kazakh President Nursultan Nazarbayev visited Prague for the first time. Additionally, the current Czech president, Miloš Zeman, is known for his "pragmatic" orientation in foreign policy, which may lead to more intensive relations with post-Soviet countries, even 
though his attempts to secure the visits of Uzbek and Turkmen presidents were not successful.

The importance of economic cooperation between the Czech Republic and Kazakhstan is growing. For example, this was visible at the Vaclav Havel Airport in Prague, where one of the terminals welcomed passengers with a billboard aiming to attracting investors to Kazakhstan. The Kazakh Republic is among twelve priority countries for export from the Czech Republic. Today, around 200 Czech companies operate in Kazakhstan, many of them in joint companies with local partners (AST-2013-12-09). The healthcare sector, transport, and energetic sectors are among the priorities in the economic sector. One of the important issues in the economic cooperation between the EU's member states and the Kazakh Republic was the establishment of a Custom Union between Russia, Belarus, and Kazakhstan. However, the Custom Union has only a limited impact on trade and economic cooperation between the Czech Republic and Kazakhstan (AST-2013-1209).

The Kazakh Republic is the third largest exporter of oil to the Czech Republic, after the Russian Federation and Azerbaijan. Oil and gas constituted almost 88\% of all imports (MFA of the Czech Republic 2014). The visit of Nursultan Nazarbayev in Prague was accompanied by a Czech-Kazakh business forum. During this event, contracts for 250 million USD were signed, and the Czech Chamber of Commerce signed an agreement of cooperation with the Kazakh National Export and Investment Agency (Vodná 2012). The Czech Republic is successful in receiving students from Kazakhstan. Kazakh students are currently the fourth largest group of international students in the Czech Republic after students from Slovakia, Russia, and Ukraine (Vrbová 2013).

Despite the fact that the Czech Republic has the image of one of the most vocal states in the EU in areas of human rights and democratization, it has not been such a visible actor in relation to Kazakhstan. There are two often mentioned reasons. Firstly, it is convenient to allow more powerful actors (such as EU institutions) a leadership role in cases of sensitive issues. Secondly, the Czech Republic has only a small embassy with limited capacity for focusing on such topics.

\section{Hungary}

"Common historical roots" are one of the important factors that helped develop relations between Hungary and Kazakhstan. Proximity in this area is accompanied by several initiatives, such as opening an Astana street in Budapest and Budapest Street in Astana. According to a Kazakh news agency, the Hungarian Prime Minister Orbán feels at home in Kazakhstan as opposed to the EU. "We are always glad to come to Kazakhstan. We are equal in political terms in the European 
Union, but genealogically we are different. When we go to Brussels, we do not have any relatives there. But when we come to Kazakhstan we have close people here. It is a strange feeling for us, but it is true. Therefore, Hungarian delegations always come to Kazakhstan with pleasure" (Hungardytoday.hu 2015). Also, other members of the Hungarian delegation declared mutual sympathy between Hungary and Kazakhstan beyond the usual diplomatic statements. The common cultural roots are obvious; our traditions still exist through the descendants of the Hungarian Cumans, who are known as Kipchaks in Kazakhstan (Eurodialogue.eu 2015).

Diplomatic relations between Kazakhstan and Hungary were already established in March 1992, the same month as the Hungarian embassy opened in Kazakhstan, with the Kazakh Embassy in Hungary opened in 1993. In November 2007, the Hungarian president visited Kazakhstan. In the opinion of the Hungarian representatives I interviewed, political relations between Hungary and Kazakhstan are excellent, and the Kazakh Republic is the most important partner of Hungary in Central Asia (AST-2013-12-05). However, Prime Minister Viktor Orbán pointed out that Hungarian-Kazakh political relations are currently much stronger than their economic relations (Hungardytoday.hu 2015). Already in 2014 Kazakhstan and Hungary signed a declaration on strategic partnership. "Hungary has consistently supported Kazakhstan's aspirations to deepen relations with the European Union, as well as its intentions to complete the process of accession to the World Trade Organisation (WTO), which we hope will happen in the near future. Hungary would support Kazakhstan in negotiations with the EU on easing visa regime as well" (Eurodialogue.eu 2015).

Kazakhstan was Hungary's third largest trading partner among the CIS member states. About 50 Kazakh-Hungarian joint enterprises are currently operating in Kazakhstan and the Hungarian Trading House, Working Group on Industry and Innovation and Intergovernmental Commission on Economic Cooperation have been established (Eurodialogue.eu 2015). The Hungarian oil industry in Kazakhstan is a flagship for developing Hungarian-Kazakh relations. The energy and health sector, infrastructure development, farming, and innovation are considered as the primary areas of bilateral cooperation (MTI 2014). The countries had decided to sign an aviation agreement with a view to launching direct flights between the two countries. Moreover, Hungary and Kazakhstan aim to relax visa regulations between the two countries. Both countries signed a preliminary agreement on the launch of a joint fund by KazAgro Holding and Eximbank (Hungardytoday.hu 2015).

\section{Poland}

Poland was among the first states that recognized the independence of Kazakhstan. Diplomatic relations between countries were established in April 1992. "Poland supported several initiatives for closer cooperation between the West and 
Kazakhstan such a tighter cooperation with NATO as part of the Partnership for Peace programme or Kazakh OSCE chairmanship" (Berski 2010, 115-116). Over 20 years, four high-level official visits took place. The President of Kazakhstan paid an official visit to Poland in 1997 and 2002, while the President of Poland visited Kazakhstan in 1999 and 2007 (Kazworld.info 2012).Most diplomatic visits of both countries' representatives have been aimed at the revival of economic contacts (Berski 2010, 119-120).

Political relations between Poland and Kazakhstan are influenced by the activities of the Open Dialogue Foundation-the Kazakh anti-Nazarbayev organization with headquarters in Poland. "Because of their activities, high-level meetings are problematic. The last meeting of our presidents was in 2007 when President Kaczynski was there. We are looking for a new meeting, the visit of Mr. Nazarbayev, but it is not easy. Without the presence of high-impact meetings, it could be hard to strengthen economic cooperation" (AST-2013-11-26). There are several practical obstacles in economic cooperation as well. "We don't have a direct flight connection with Kazakhstan that is costly and time-consuming. Another problem is visa-you can't be sure that, as a business person, you will get visa long enough to work there. One more obstacle for investors is that they have to use local workers and local services, while also fulfilling their requirements, which can be problematic" (AST-2013-11-26).

Despite these obstacles "the importance of Kazakhstan for Poland is growing, because of growing Polish export to the region. There is also a growing number of Polish investments in Kazakhstan. Our investments are concentrated in the energy sector. We have a very successful company in the pharmaceutics industry, which is probably the biggest investor in this sector here" (AST-2013-11-26). There are two Kazakh plans, which are also strongly supported in Poland. The first one is the Kazakh idea of a new Silk Road from China to Europe. "We hope that Poland could be one of the logistics centers for goods from China in the future. Polish authorities support this Kazakh project, and we would like to cooperate on its building" (AST-2013-11-26). The second project is green energy. From these plans is evident why economic cooperation has priority. It is also understandable why Poland also prefers that European Union institutions raise sensitive issues.

Poland is the largest of the V4 countries, with a relatively strong position within the European Union, nevertheless "it has only played a modest role with respect to EU policy towards Central Asia. However, it has special interests in Kazakhstan, because there is a small Polish diaspora" (Gower 2010, 42-43). The diaspora includes more than 40,000 people, and it provides Poland with larger possibilities and tools for cooperation. "We try to develop this diaspora in education and learning of Polish language. That is the reason why we offer them scholarships in universities in Poland. But part of this program is also for Kazakh people" (AST-2013-11-26). Another area of cooperation is in education, similarly 
to the Czech Republic. "As part of the 2008 'Now Wroclaw' campaign, Polish Wroclaw universities were searching for students from CIS countries, including Kazakhstan. The Polish side also pays scholarships for international students" (Berski 2010, 117).

\section{Slovakia}

Although Slovakia is the smallest of the V4 countries, in terms of European and world diplomacy toward Central Asia can be considered a superpower. Its diplomatic representatives in international organizations have played a major role in fostering relations with the region. For example, Ján Kubiš was the first EU special representative for Central Asia, and later the Minister of Foreign Affairs of Slovakia. Furthermore, Miroslav Jenča, another Slovak diplomat, oversaw the United Nations Regional Centre for Preventive Diplomacy for Central Asia in from 2008 to 2015. Moreover, the state secretary of the Ministry of Foreign and European Affairs of the Slovak Republic, Peter Burian, became the EU Special Representative for Central Asia in 2015.

Nevertheless, these nominations had only a limited impact on the relations between Slovakia and Kazakhstan or Central Asia. Most progress has happened in term of meetings of political representatives. "The activation of liaison activities in the recent period was reaffirmed by the first official visit of President Nursultan Nazarbayev of Kazakhstan in Slovakia in November 2007 and official visits of Jan Kubiš, Minister of Foreign Affairs of the Slovak Republic in Kazakhstan in March 2007 and October 2008" (Podhorský 2010, 57). In 2010, Slovak President Ivan Gašparovič visited Kazakhstan and his photo from the visit on Koktobe Hill in Almaty is still there among other photos of the location. In the middle of 2013, the speaker of the Slovak parliament visited Kazakhstan and held meetings with Kazakh representatives, including the Heads of Senate. He has received an honorary professor title at the L.N. Gumilyov Eurasian National University. Additionally, the Slovak Parliament has established a "group of friendship," which includes all Central Asian countries and other post-Soviet states.

Exports from Kazakhstan to Slovakia in 2012 consisted mainly of mineral fuels and oils, as well as iron and steel. On the other hand, exports from Slovakia to Kazakhstan included electrical machines and equipment, mechanical machinery, optical equipment, paper, rubber and pharmaceutical products (Sario 2013). A mutual business forum was held in 2013, preparing the preconditions for new Slovak -Kazakh agreements and creating possibilities for investments in the Kazakh Republic. One surprising example of cooperation is collaboration between the Kazakh army and one of Slovak training simulation supplier companies (Jurašková 2013).

One of the disadvantages of Slovakia, when compared with the rest of 
Visegrad countries, is the limited exchange of students and academics and the restricted possibilities for Kazakh students to study in Slovakia, despite the intergovernmental agreement in this area and cooperative arrangements between Slovak and Kazakh universities. Contrary to the other V4 countries, there is no university focusing on receiving students from Kazakhstan or Central Asia in general. Problems include the lower quality of universities and the limited possibilities for studying in languages other than Slovak.

Moreover, Slovakia stopped development assistance in the region. "Kazakhstan belonged to priority countries of Slovak official development aid. In the period 2004-2009, there were 13 projects approved for that country. Projects approved for Kazakhstan mostly focused on supporting small and medium enterprises, civil society support and water and energy management" (Podhorský 2010, 61). The improving economic situation in Kazakhstan was one of the main reasons for stopping development assistance. Another area of cooperation is an agreement between the General Prosecution of the Slovak Republic and general prosecution of the Kazakh Republic from 2013, which should result in a Memorandum on legal cooperation in criminal matters at the level of general prosecutors (Generálna prokuratúra SR 2013).

\section{CONCLUSION}

European Union policy toward Central Asia, together with foreign policies of member states, has created two interconnected policies toward the region that are meeting in the "two-level game." Although "European' foreign policy and foreign policies of EU members" states are closely linked, member states would prefer the division of roles-if it is in their national interests. European Union institutions along with member states need to balance their "values" such as human rights and democracy promotion and their "interests" like developing economic and trade ties. The Central Asian region provides an excellent opportunity to evaluate this game due to "partnerships" in the form of the Strategy as well as thanks to Partnership and Cooperation agreements. The relation between Visegrad countries in central Europe and Kazakhstan is used as case study. One of the reasons is that Kazakhstan is the most important state in Central Asia with the most developed relations with the EU and member states.

Representatives of Visegrad countries confirmed the "two-level game" in the case of Kazakhstan, where responsibility for controversial areas rests on European institutions, while member states are involved mainly on a voluntary basis. On the other hand, member states can avoid sensitive issues and focus on their primary goal-developing economic relations. Relations of all four Visegrad countries with Kazakhstan are on a satisfactory level. The top priority for them lies in economic relations. The majority of activities focus on this area, and all countries have made 
recent steps for increasing cooperation, such as intergovernmental agreements, commissions and economic forums. Nevertheless, their cooperation with the EU institutions in issues such as human rights and democracy promotion is quite limited.

The roots of this game could be found in a Central Asia strategy that identifies human rights dialogue and democracy promotion as one of the priorities in relations with these countries. European institutions have taken the responsibility for political ties with Kazakhstan, as well as problematic areas like democracy promotion and human right dialogue. The representatives of member states and the institutions declared satisfaction with progress. It is fact that political contacts are more developed and intensified than before the Strategy. Moreover, EU institutions have played an active role in raising sensitive issues, which then allow to EU member states embassies, usually with a limited number of recourses and staffs, to focus on their priorities.

One of the main findings of the article is the confirmation of division of roles between European Union institutions and the member states, at least in the case of relations with Kazakhstan. Kazakhstan has become one of the most important partners in the Central Asian regions, and both EU institutions and European countries are attempting to find ways to increase cooperation. Simultaneously, relations with Kazakhstan are an excellent example of two-level games. Although the existence of such game is hardly surprisingly in a situation where European Union institution and member states have an opportunity to formulate foreign policies, there remain many questions for further research. For instance, is the two levels game present in other EU external policies? Is the preference of "interests" over "values" a typical feature of Visegrad foreign policies in other regions?

\section{REFERENCES}

Berski, Adrian. 2010. "Realization of Bilateral Relations between the Republic of Poland and the Republic of Kazakhstan.” Buletinul Cercurilor Ştiințifice Studențeşti 16: 114-122.

Boas, Vanessa. 2012. "Energy and Human Rights: Two Irreconcilable Foreign Policy Goals? The Case of the Trans-Caspian Pipeline in EU-Turkmen Relations." IAI Working Papers. Accessed July 15, 2016, http://www.iai.it/sites/ default/files/iaiwp1207.pdf

Boonstra, Jos. 2011. "The EU's Interests in Central Asia: Integrating Energy, Security and Values into Coherent Policy." Accessed July 15, 2016, http:// www.edc2020.eu/fileadmin/publications/EDC_2020 Working paper_No 9 The EU\%E2\%80\%99s Interests in Central Asia v2.pdf

Eurasian Council on Foreign Affairs. 2014. "New Successful Round of Negotiations between Kazakhstan and the EU." Accessed July 14, 2016, http:// www.eurasiancouncilforeignaffairs.eu/publications/bulletins/ 
European Court of Auditors. 2014. "EU Assistance to Central Asia is Well Planned, but Implementation Slow and Variable-Say EU Auditors." Accessed July 16, 2016, http://europa.eu/rapid/press-release ECA-14-3 en.pdf

Eurodialogue.eu. 2015. "Hungary Continues to Aim to Develop Cooperation with Kazakhstan." Accessed July 16, 2016, http://www.eurodialogue.eu/Hunga ry\%20continues $\% 20$ to $\% 20$ aim $\% 20$ to $\% 20$ develop $\% 20$ cooperation $\% 20$ with $\%$ 20Kazakhstan

Generálna prokuratúra SR. 2013. "Generálny prokurátor Kazachstanu bol na Slovensku.” Accessed July 15, 2016, http://www.genpro.gov.sk/spravy-1267. $\underline{\mathrm{html}}$ id $=2451$

Gower, Jackie. 2010. "EU Member States in Central Asia." In The European Union and Central Asia Edited by Alexander Warkotsch, 33-47. Abingdon: Routledge.

Hungarytoday.hu. 2015. "Hungary, Kazakhstan Agree to Strengthen Political and Economic Relations." Accessed July 16, 2016, http://hungarytoday.hu/news/ hungary-kazakhstan-agree-strengthen-political-economic-relations-87782

Jurašková, Tatiana. 2013. "Kazašská armáda verí Slovákom. Núka milióny." Accessed July 14, 2016, http://hn.hnonline.sk/ekonomika-a-firmy-117/kazass ka-armada-veri-slovakom-nuka-miliony-561359

Kassenova, Nargis. 2008. "A View from the Region." In Engaging Central Asia. The European Union's new Strategy in the Heart of Eurasia, edited by Neil J. Melvin, 122-136. Centre for European Policy Studies.

Kassenova, Nargis. 2010. "EU-Central Asian Bilateral Cooperation." In The European Union and Central Asia edited by Alexander Warkotsch, 48-62. Abingdon: Routledge.

Kazworld.info. 2012. "Poland and Kazakhstan Want to Strengthen Cooperation." Accessed July 14, 2016, http://kazworld.info/? $\mathrm{p}=22395$

Manners, Ian. 2002. Normative Power Europe: A Contradiction in Terms? Journal of Common Market Studies 40(2): 235-258.

MFA of the Czech Republic. 2014. "Obchodní a ekonomická spolupráca s ČR." Accessed July 14, 2016, http://www.mzv.cz/jnp/cz/encyklopedie statu/asie/ kazachstan/ekonomika/obchodni a ekonomicka spoluprace s cr.html

MTI. 2014. "Hungary for Deepening Ties with Kazakhstan, says Martonyi." Accessed July 15, 2016, http://www.politics.hu/20140128/hungary-for-deepen ing-ties-with-kazakhstan-says-martonyi/

OHCHR Regional Office for Europe. 2011. "The European Union and International Human Rights Law." Accessed November 25, 2016, http://www. europe.ohchr.org/Documents/Publications/EU and International Law.pdf

Pérez de las Heras, Beatriz. 2015. "EU and US External Policies on Human Rights and Democracy Promotion: Assessing Political Conditionality in Transatlantic Partnership." Romanian Journal of European Affairs 15(2): 80-96. 
Podhorský, Dušan. 2010. "Potential of the Development of Slovak-Kazakhstani Cooperation." In Building Bridges between Slovakia and Kazakhstan: Policy Forums and Sharing Transition Experience edited by Vladimír Benč, 57-81. Bratislava: Research Centre of the Slovak Foreign Policy Association.

Romanowski, Michal. 2014. "Central Europe Calling Central Asia, Over?" In Visegrad Insight, Accessed July 15, 2016, http://visegradinsight.eu/central-euro pe-calling-central-asia-over01122014/

Romanowski, Michal. 2016. "The EU in Central Asia: The Regional Context." Directorate-General for Externalpolicies. Policy Department. European Parliament. Accessed July 15, 2016, http://www.europarl.europa.eu/RegData/ etudes/IDAN/2016/535020/EXPO_IDA(2016)535020_EN.pdf

Sario. 2013. "Kazachstan.” Accessed July 15, 2016, http://www.sario.sk/sites/defa ult/files/content/files/Kazachstan.pdf

Sedelmeier, Ulrich. 2006. "The EU's Role as a Promoter of Human Rights and Democracy: Enlargement Policy Practice and Role Formation.” In Elgstrom, O.-Smith, M. The European Union's Roles in International Politics. Concepts and Analysis. London:Routledge. 118-135.

Stepniewski, Tomasz. 2012. "The European Union's Policy towards Central Asia." The New Great Game in Central Asia, 115-142. Lublin: Instytut Europy Środkowo-Wschodniej.

The EU and Central Asia: Strategy for a New Partnership. 2007. Accessed July 14, 2016, http://register.consilium.europa.eu/doc/srv?1=EN\&t=PDF\&gc $=$ true $\underline{\mathrm{sc}}=$ false $\& \mathrm{f}=\mathrm{ST} \% 2010113 \% 202007 \% 20 \mathrm{INIT}$

Tsertsvadze, Tika and Jos Boonstra. 2013. "Mapping EU Development Aid to Central Asia." EUCAM Factsheet 1. Accessed July 14, 2016, http://www.eu centralasia.eu/uploads/tx_icticontent/EUCAM-FS-1-EN.pdf

Tsertsvadze, Tika and Vera Axyonova. 2013. "Trading Values with Kazakhstan." EUCAM Policy Brief No. 32. Accessed July 14, 2016, http://www.fride. org/download/EUCAM-PB-32-Trading-values-KZ-EN ok.pdf

Vodná, Lenka. 2012. "HK ČR podepsala memorandum o porozumění s Kaznex Invest.” Accessed July 14, 2016, http://www.komora.cz/hk-cr-podepsala-me morandum-o-porozumeni-s-kaznex-invest.aspx

Vrbová, Daniela. 2013. "Jak kazašští studenti přicházejí do Česka.” Accessed July 14, 2016, http://www.rozhlas.cz/plus/cizinci/_zprava/jak-kazassti-studenti-pr ichazeji-do-ceska-1188018

Yazdani, Enayatollah. 2008. "The European Union and Central Asia." International Studies 45(3): 247-55.

Youngs, Richard. 2016. "EU Global Strategy: How to Balance Interests and Values." Carnegie Europe. Accessed July 14, 2016, http://carnegieeurope.eu/2016/ 01/15/eu-global-strategy-how-to-balance-interests-and-values/it0q 


\section{List of interviews:}

ALM-2013-12-12. Political scientist, $12^{\text {th }}$ December 2013, Almaty, Kazakhstan. ALM-2013-12-12b. Political scientist, $12^{\text {th }}$ December 2013, Almaty, Kazakhstan. AST-2013-11-26. V4 country embassy representative, 26 ${ }^{\text {th }}$ November 2013, Astana, Kazakhstan.

AST-2013-11-27. EU country ambassador in Kazakhstan, 27 ${ }^{\text {th }}$ November 2013, Astana Kazakhstan.

AST-2013-12-05. V4 country embassy representative, $5^{\text {th }}$ December 2013. Astana, Kazakhstan.

AST-2013-12-09. V4 country embassy representative, $9^{\text {th }}$ December 2013. Astana, Kazakhstan.

BRU-2013-10-23. European External Action Service representative, 23th October 2013. Brussels, Belgium.

BRU-2013-10-24. V4 country representative in Council Working Party on Eastern Europe and Central Asia (COEST), $24^{\text {th }}$ October 2013. Brussels, Belgium. 


\section{ENDNOTES}

1 Working Group for Eastern Europe, South Caucasus and Central Asia of the EU Council.

2 For more information: http://ec.europa.eu/trade/policy/countries-and-regions/countries/kazakhstan/

3 At least 14 people were killed by police during protests in the town Zhanaozen.

4 Former High Representative of the Union for Foreign Affairs and Security Policy.

5 Similar agreements were also signed and came into force with Uzbekistan, Kyrgyzstan and Tajikistan. The PCA with Turkmenistan has been signed in 1998 however, it has not yet been ratified.

${ }^{6}$ For more information: http://pdc.ceu.hu/archive/00006527/01/IPA Czech-Republic-democracy-pro motion-policies-priorities 2011.pdf and http://carnegieendowment.org/2014/10/16/polish-demo cra cy-promotion-in-ukraine-pub-56907 